\title{
OPTIMIZATION OF REDUCED FAT MAYONNAISE BY USING APPLE PEEL FLOUR AS A STABILIZER
}

\author{
Herly Evanuarini ${ }^{1)}$, Agus Susilo ${ }^{1)}$ \\ 1) Department of Animal Products Technology, Faculty of Animal Science, Universitas Brawijaya, Jl. Veteran, \\ Kota Malang, East Java, Indonesia, 65145 \\ *Corresponding Email: herlyfptub@ub.ac.id
}

Submitted 13 October 2021; Accepted 29 November 2021

\begin{abstract}
Reduced fat mayonnaise products have an unstability of the emulsion, so a stabilizer is needed to improve quality of mayonnaise. Apple peel flour can be used as a stabilizer to improve the quality of mayonnaise. The materials used in this study were vegetable oil, egg yolk, vinegar, apple peel flour and other optional ingredients. The research treatment was without the addition of apple peel flour as a control, the use of $1 \%, 2 \%$ and $3 \%$ apple peel flour. The objective of this research was to determine the best percentage of apple peel flour as a stabilizer in reduced fat mayonnaise. The research method used is a laboratory experiment method. The design used was a completely randomized design with 4 treatments and 4 replications. Analysis of variance was used to analyze the resulting data, if there was a difference in the effect, it was continued with Duncan's Multiple Range Test.This study resulted that the use of apple peel flour used as a stabilizer resulted gave highly significant difference in reduced fat mayonnaise. The average acidity is $0.66-0.90$, the emulsion stability is $96.92-$ $99.18 \%$, the antioxidant activity is $8.37-19.38 \%$, the carbohydrate content is $2.63-5.81 \%$ and ash by $1.72-1.92 \%$. It could be concluded that the use of $3 \%$ apple peel flour can produce the best quality reduced fat mayonnaise product and is close to the characteristics of full fat mayonnaise.
\end{abstract}

Key words: Apple peel powder; reduced fat mayonnaise; stabilizer 


\section{INTRODUCTION}

Manalagi apple peel waste is mostly found in processed apple chips and apple cider factories. Both of these plants can produce 5 tons of waste. Manalagi apple peel waste in Batu Malang City is widely used as ruminant animal feed mixed with other feeds. Apple peel can also be used as a source of pectin which is used as a stabilizer. The stabilizer is used as an emulsion stabilizer which aims to increase the stability of the emulsion and is expected to maintain the stability of the emulsion during storage. Apple peel flour also contains several secondary metabolites that are antioxidative, including alkaloids, phenols, terpenoids, steroids, and flavonoids.

Mayonnaise is a type of oil in water emulsion $(\mathrm{o} / \mathrm{w})$. The problem that occurs in full-fat mayonnaise is that it has a high-fat content, therefore various efforts have been made to reduce the fat content but have characteristics similar to full-fat. One effort that can be done is to reduce the dispersed phase and increase the dispersion phase. Reduced-fat mayonnaise uses vegetable oil as the dispersing phase as much as $50 \%$ of the total ingredients used. The water phase is used in the form of vinegar and vegetable oil as the oil phase requires a stabilizer. Several studies on the use of stabilizers include hydrocolloids. One of the materials that can be used as a stabilizer is manalagi apple peel waste.

Manalagi apple peel contains pectin about $40.7 \%$ of the fruit weight (Subagyo, and Ahmad. 2010). The proximate content of apple peel is $2.80 \mathrm{~g} / 100 \mathrm{~g}$ of crude protein, $9.96 \mathrm{~g} / 100 \mathrm{~g}$ of crude fat, $1.39 \mathrm{~g} / 100 \mathrm{~g}$ of ash content, $13.95 \mathrm{~g} / 100 \mathrm{~g}$, and $59.96 \mathrm{~g} / 100 \mathrm{~g}$, contains calcium minerals of 14.89 $\mathrm{mg} / 100 \mathrm{~g}, \quad 0.95 \mathrm{mg} / 100 \mathrm{~g}$ zinc, 25.63 $\mathrm{mg} / 100 \mathrm{~g}$ iron and $1.28 \mathrm{mg} / 100 \mathrm{~g}$ manganese (Romelle, et al. 2020). The pectin can increase the formation of mayonnaise emulsion stability, reduce acidity, increase antioxidant activity, increase carbohydrate content and ash content in reduced-fat mayonnaise.

\section{MATERIALS AND METHODS}

This study used laboratory research methods and used a completely randomized design. The treatments used were 4 treatments and 4 replications. The treatments used were without manalagi apple peel flour as a control, the addition of $1 \%$ manalagi apple peel flour (P1), 2\% manalagi apple peel flour (P2), and 3\% manalagi apple peel flour (P3). The reducedfat mayonnaise formulation can be seen as follows:

Table 1. Reduced fat mayonnaise formulation

\begin{tabular}{lcccc}
\hline Ingredient (\%) & Control & T1 & T2 & T3 \\
\hline Canola Oil & 70 & 50 & 50 & 50 \\
Eggs yolk & 15 & 15 & 15 & 15 \\
Apple peel flour & 0 & 1 & 2 & 3 \\
Vinegar & 5 & 5 & 5 & 5 \\
Salt & 1.5 & 1.5 & 1.5 & 1.5 \\
Sugar & 2.5 & 2.5 & 2.5 & 2.5 \\
Mustard & 0.5 & 0.5 & 0.5 & 0.5 \\
White Pepper & 0.5 & 0.5 & 0.5 & 0.5 \\
\hline
\end{tabular}

*Corresponding author:

Herly Evanuarini

Email: herlyfptub@ub.ac.id

Department of Animal Products Technology, Faculty of Animal Science, Universitas Brawijaya, Jl. Veteran, Kota Malang, East Java, Indonesia, 65145
How to cite:

Evanuarini, H., \& Susilo, A. (2021). Optimization of Reduced Fat Mayonnaise by Using Apple Peel Flour as a Stabilizer. Jurnal Ilmu dan Teknologi Hasil Ternak (JITEK), 16 (3), 174-180 
The preparation of apple peel flour is done by drying the cleaned apple peel in a drying oven at 60 degrees for 46 hours, then the apple peel is mashed and filtered through a 100 mesh sieve. The process of sample mayonnaise is done by mixing the ingredients (sugar, salt, pepper, and mustard) using a hand mixer at $1500 \mathrm{rpm}$ for 1 minute, then adding egg yolks, canola oil and alternating with vinegar, then adding flour apple peel and homogenized until an emulsion is formed (Evanuarini, et al. 2016) with the modification of. The data that has been obtained then perform analysis of variance (ANOVA). If the results are obtained had a significant or highly significant difference, then continued with Duncan's Multiple Range Test.

\section{RESULTS AND DISCUSION}

\section{Acidity}

Data and analysis of various acidity levels of reduced-fat mayonnaise with the addition of manalagi apple peel flour gave highly significant effect $(\mathrm{P}<0.01)$ on the acidity level of mayonnaise. The mean value of reduced-fat mayonnaise acidity with the addition of manalagi apple peel flour can be seen in Table 2.

Table 2. The Average Value of Acidity Level of Reduced Fat Mayonnaise

\begin{tabular}{cc}
\hline Treatment & Acidity Level \\
\hline P0 & $0.90 \pm 0.02^{\mathrm{d}}$ \\
P1 & $0.81 \pm 0.03^{\mathrm{c}}$ \\
P2 & $0.72 \pm 0.02^{\mathrm{b}}$ \\
P3 & $0.66 \pm 0.03^{\mathrm{a}}$ \\
\hline
\end{tabular}

Note: Different superscripts in the same column show a highly significant difference $(\mathrm{P}<0.01)$

Table 2 shows that the acidity of reduced-fat mayonnaise with the addition of apple peel flour with different percentages tends to decrease. The average value of the acidity of mayonnaise is $0.66-0.90$. The highest acidity level was found in control mayonnaise (P0) and the lowest acidity level was mayonnaise with the addition of $3 \%$ manalagi apple peel flour (P3).

The more addition of apple peel flour to reduced-fat mayonnaise, then the average value of the acidity of the mayonnaise will increase. This is because pectin is a carboxylic group and is acidic (Amelia et al. 2016). Pectin is also a D-galacturonic polymer linked by $-1,4$ glycosidic bonds which play a role in lowering $\mathrm{pH}$. The use of pectin materials affects the stability of the emulsion (Ngouemazong, et al. 2018). The degree of acidity $(\mathrm{pH})$ is used to determine the level of acidity of a material. The acidity in question is the concentration of hydrogen ions $(\mathrm{H}+)$ in the water solvent (Dewi, Antarini, and Puryana, 2013). According to
Falah, et al (2020), the pH level of pectin derived from apples is around 2.0-4.0. The acidity of mayonnaise with pectin content results in several 0.7-0.8 (Johary, et al. 2015).

\section{Emulsion stability}

The addition of manalagi apple peel flour gave highly significant effect $(\mathrm{P}<0.01)$ on the stability of the mayonnaise emulsion. The average value of the stability of the reduced-fat mayonnaise emulsion with the addition of manalagi apple peel flour can be seen in Table 3.

Emulsion stability in reduced fat mayonnaise with the addition of apple peel flour with different percentages increased. The average value of the stability of the mayonnaise emulsion ranged from 96.92$99.18 \%$. The highest emulsion stability was found in mayonnaise with the addition of $3 \%$ apple peel flour (P3) and the lowest emulsion stability was mayonnaise without the addition of apple peel flour. 
Table 3. The Average Stability Value of Reduced Fat Mayonnaise Emulsion

\begin{tabular}{cc}
\hline Treatment & Emulsion stability (\%) \\
\hline P0 & $96.92 \pm 0.11^{\mathrm{a}}$ \\
P1 & $97.18 \pm 0.04^{\mathrm{b}}$ \\
P2 & $98.82 \pm 0.10^{\mathrm{c}}$ \\
P3 & $99.18 \pm 0.04^{\mathrm{d}}$ \\
\hline
\end{tabular}

Note: Different superscripts in the same column show highly significant difference $(\mathrm{P}<0.01)$

With the more addition of apple peel flour to reduced-fat mayonnaise, the average value of the stability of the mayonnaise emulsion will increase. This is due to the nature of pectin in apple peel flour can form a gel and increase the viscosity of the mayonnaise emulsion.

The nature of pectin can form a gel when combined with water and acid (Amelia, et al. 2016). Emulsion stability is an important parameter to determine durability during storage and mayonnaise using pea pod powder produces $99.86 \%$ emulsion stability (Rudra, et al. 2020). Mutiah (2002) explained that the stability of the emulsion is influenced by the balance of the proportion between protein and water. If the amount of protein is not proportional to the amount of water, it can cause water to separate because the protein is not able to bind high amounts of water so that it will cause low emulsion stability. Vegan mayonnaise using durian gum seeds resulted in emulsion stability of $80.34 \%$ (Cornelia, et al. 2015).

\section{Antioxidant activity}

The addition of manalagi apple peel flour gave highly significant effect $(\mathrm{P}<0.01)$ on the antioxidant activity of mayonnaise. The average value of the antioxidant activity of reduced-fat mayonnaise with the addition of manalagi apple peel flour can be seen in Table 4.

Table 4. Average Value of Antioxidant Activity of Reduced Fat Mayonnaise

\begin{tabular}{cc}
\hline Treatment & Antioxidant activity (\%) \\
\hline P0 & $8.70 \pm 0.56^{\mathrm{a}}$ \\
P1 & $13.09 \pm 0.32^{\mathrm{b}}$ \\
P2 & $16.59 \pm 0.42^{\mathrm{c}}$ \\
P3 & $19.38 \pm 0.24^{\mathrm{d}}$ \\
\hline
\end{tabular}

Note: Different superscripts in the same column show a very significant difference $(\mathrm{P}<0.01)$

The antioxidant activity of reduced-fat mayonnaise with the addition of apple peel flour with different percentages increased. The average antioxidant activity of mayonnaise was $8.70-19.38 \%$. The highest antioxidant activity was found in mayonnaise with the addition of $3 \%$ apple peel flour (P3) and the lowest antioxidant activity was control mayonnaise.

The higher the addition of manalagi apple peel flour in reduced-fat mayonnaise, the average value of the antioxidant activity of mayonnaise will increase. This is because manalagi apple peel flour contains $55.77 \%$ of antioxidants (based on preliminary research). The IC50 value (50\% inhibitor concentration) is a concentration that can absorb $50 \%$ of DPPH free radicals, so the smaller the IC50 value, the greater the antioxidant. Compounds that can be said to be very strong antioxidants have IC50 values of less than $50 \mathrm{ppm}$, strong IC50 of $50-100 \mathrm{ppm}$, moderate IC50 of 100-200 ppm, and weak IC50 of more than 200 ppm. Apple peel flour also contains several secondary metabolites that are antioxidative, including alkaloids, phenols, terpenoids, steroids, and flavonoids. Materials containing vitamin $\mathrm{E}$ can also increase antioxidant activity (Johary, et al. 2015). Types of antioxidant content in apple peels are procyanidin, catechin, epicatechin, 
chlorogenic acid, phloridzin, and quercetin conjugates (Gunathilake and Considine, 2018). Components such as flavonoids, terpenoids, and phenolics can significantly affect antioxidants (Gomes, et al. 2016).

\section{Carbohydrate Level}

The addition of manalagi apple peel flour gave a highly significant effect $(\mathrm{P}<0.01)$ on the carbohydrate content of mayonnaise. The average value of reducedfat mayonnaise carbohydrate content with the addition of manalagi apple peel flour can be seen in Table 5 .

Table 5 showed that the carbohydrate content of reduced-fat mayonnaise with the addition of apple peel flour with different percentages increased. The average value of the carbohydrate content of mayonnaise is $2.63-5.81 \%$. The highest carbohydrate content was found in mayonnaise with the addition of $3 \%$ apple peel flour (P3) and the lowest carbohydrate content was mayonnaise without treatment.

Table 5. The Average Value of Carbohydrate Content of Reduced Fat Mayonnaise

\begin{tabular}{cc}
\hline Treatment & Carbohydrate Content (\%) \\
\hline P0 & $2.63 \pm 0.13^{\mathrm{a}}$ \\
P1 & $4.16 \pm 0.64^{\mathrm{b}}$ \\
P2 & $5.02 \pm 0.31^{\mathrm{c}}$ \\
P3 & $5.81 \pm 0.07^{\mathrm{c}}$ \\
\hline
\end{tabular}

Note: Different superscripts in the same column show highly significant difference $(\mathrm{P}<0.01)$

Table 5 shows that the more apple peel flour is added to reduced-fat mayonnaise, the higher the average value of the carbohydrate content of mayonnaise will be. This is because of the carbohydrates in apple peel flour, one of which is pectin. Pectin is a galacturonic acid polymer that contains polysaccharide acid and can bind water so that it is a thickener (Nadir, et al. 2019).

The stability of the emulsion in mayonnaise can be improved with carbohydrates, the function of carbohydrates as thickeners (Safitri, Evanuarini, and Thohari 2019). The sugars in mayonnaise can bind to pectin to form strong hydrogen bonds and become a complex polysaccharide network (Shin, et al. 2002). The higher carbohydrate content is also caused by the higher acidity in mayonnaise. This is because the more hydrogen ions that can hydrolyze protopectin into pectin, can increase the yield, which also means the carbohydrate content will also increase (Nadir, et al. 20219). According to Fernandes and Myriam (2017) in the study of low-fat mayonnaise, carbohydrates increased influenced by the level of concentration of chia mucilage as a substitute for oil. According to Araujo, et al. (2014) the increase in carbohydrates is influenced by the dissolved material and the stability of the emulsion formed in mayonnaise.

\section{Ash Level}

Data and analysis of variance in ash content of reduced-fat mayonnaise with the addition of manalagi apple peel flour gave highly significant effect $(\mathrm{P}<0.01)$ on the ash content of mayonnaise. The average value of reduced-fat mayonnaise ash content with the addition of manalagi apple peel flour can be seen in Table 6.

Table 5 showed that the carbohydrate content of reduced-fat mayonnaise with the addition of apple peel flour with different percentages increased. The average value of the carbohydrate content of mayonnaise is $2.63-5.81 \%$. The highest carbohydrate content was found in mayonnaise with the addition of 3\% apple peel flour (P3) and the lowest carbohydrate content was mayonnaise without treatment. 
Table 6. Average Value of Ash Content of Reduced Fat Mayonnaise

\begin{tabular}{cc}
\hline Treatment & Ash Content (\%) \\
\hline P0 & $1.72 \pm 0.03^{\mathrm{a}}$ \\
P1 & $1.78 \pm 0.05^{\mathrm{b}}$ \\
P2 & $1.88 \pm 0.04^{\mathrm{c}}$ \\
P3 & $1.92 \pm 0.03^{\mathrm{d}}$ \\
\hline
\end{tabular}

Note: Different superscripts in the same column show highly significant difference $(\mathrm{P}<0.01)$

Table 6 shows that the ash content of reduced-fat mayonnaise with the addition of apple peel flour with different percentages increased. The average value of the ash content of mayonnaise is $1.72-1.92 \%$. The highest ash content was found in mayonnaise with the addition of $3 \%$ apple peel flour (P3) and the lowest ash content was mayonnaise without treatment.

Table 6 shows that the more apple peel flour is added to reduced-fat mayonnaise, the higher the ash content of mayonnaise will be. This is because apple peel flour also has an ash content. Based on preliminary research, the ash content in apple peel flour is $4.54 \%$. Ash is the residue of burning organic matter to produce inorganic materials (Nuh, et al. 2017). According to Romelle, et al (2020) explained that the ash content in $100 \mathrm{~g}$ of dried apple peels includes $14.89 \mathrm{mg}$ calcium, $0.95 \mathrm{mg}$ zinc, $25.63 \mathrm{mg}$ iron, and $1.28 \mathrm{mg}$ manganese. The more apple peel flour added to the mayonnaise, the higher the ash content was because the calcium, zinc, iron, and manganese content in the mayonnaise also increased. The ash content in apple skin is about 0.06-0.35\% (Falah, et al. 2020). It is very possible that the ash content of mayonnaise also increased significantly.

\section{CONCLUSION}

It can be concluded that the use of apple peel flour as much as $3 \%$ resulted in the best-reduced fat mayonnaise with an acidity of 0.66 , emulsion stability of $99.18 \%$, the antioxidant activity of $19.38 \%$, the carbohydrate content of $5.81 \%$, and ash content. by $1.92 \%$, and close to the characteristics of full-fat mayonnaise.

\section{REFERENCES}

Amelia, O., Astuti, S., \& Zulferiyenni. (2016). Pengaruh penambahan pektin dan sukrosa terhadap sifat kimia dan sensori selai jambu biji merah (Psidium guajava L.). Prosisding Seminar Nasional Pengembangan Teknologi Pertanian, September, 149-159.

Araújo, V. B. S., Melo, A. N. F., Costa, A. G., Gomez, R. H. C., Madruga, M. S., Souza, E. L., \& Magnani, M. (2014). Followed extraction of $\beta$-glucan and mannoprotein from spent brewer's yeast (Saccharomyces uvarum) and application of the obtained mannoprotein as a stabilizer in mayonnaise. Innovative Food Science \& Emerging Technologies, 23, 164170. https://doi.org/10.1016/j.ifset.20 13.12.013

Cornelia, M., Siratantri, T., \& Prawita, R. (2015). The utilization of extract durian (Durio zibethinus L.) seed gum as an emulsifier in vegan mayonnaise. Procedia Food Science, 3, 1-18. https://doi.org/10.1016/j.profoo.2015. 01.001

Dewi, A. R. T., Antarini, N., \& Puryana, I. G. P. S. (2013). Perbedaan waktu pemanasan albedo kulit jeruk bali terhadap mutu jam kulit jeruk bali. Jurnal Gizi, 4(2), 144-153.

Evanuarini, H., Nurliyani, Indratiningsih, \& Hastuti, P. (2016). Kestabilan emulsi dan karakteristik sensoris low fat mayonnaise dengan menggunakan kefir sebagai emulsifier replacer. Jurnal Ilmu Dan Teknologi Hasil Ternak, 11(2). 
Falah, D. P., Kurniaty, N., \& Aprilia, H. W. (2020). Pembuatan dan Karakterisasi Edible Film dari Pektin Buah Apel Hijau. Prosiding Farmasi, 6(1), 1-6.

Fernandes, S. S., \& Mellado, M. de las M. S. (2018). Development of mayonnaise with substitution of oil or egg yolk by the addition of chia ( Salvia Hispânica L.) mucilage. Journal of Food Science, 83(1), 74-83. https://doi.org/ 10.1111/1750-3841.13984

Gomes, I., Lindenblatt, C., Masson, L. M., Gomes, F. d., Freitas-Silva, O., \& Silva, P. (2016). Effect of oregano essensial oil on oxidative stability of low-acid mayonnaise. IOSR Journal of Pharmacy, 6(11), 45-52.

Gunathilake, C., \& Considine, M. (2018). Flavonoids rich apple for healthy life. MOJ Food Processing \& Technology, 6(1), 89-91. https://doi.org/10.15406/ mojfpt.2018.06.00149

Hutapea, C., Rusmarilin, H., \& Nurminah., M. (2015). Pengaruh perbandingan zat penstabil dan konsentrasi kuning telur tehadap mutu reduced fat mayonnaise. Jurnal Rekayasa Pangan Dan Perternakan, 4(3), 304-311.

Johary, N., Fahimdanesh, M., \& Garavand, F. (2015). Effect of basil seed gum and tracaganth gum as fat replacers on physicochemical, antioxidant and sensory properties of low fat mayonnaise. International Journal of Engineering Science Invention, 4(1), 51-57.

Mutiah. (2002). Perbandingan Mutu Mayones Telur Ayam dan Mayones Telur Itik. Institut Pertanian Bogor.

Nadir, M., Latifah, F., \& Meylinda, P. (2019). Rendemen dan karakteristik pektin dari kulit nenas dan kulit buah naga dengan microwave assisted extraction (MAE). Prosiding Seminar
Nasional Penelitian Dan Pengabdian Masyarakat, 124-128.

Ngouémazong, E. D., Christiaens, S., Shpigelman, A., Van Loey, A., \& Hendrickx, M. (2015). The emulsifying and emulsion-stabilizing properties of pectin: a review. Comprehensive Reviews in Food Science and Food Safety, 14(6), 706718. https://doi.org/10.1111/1541-433 7.12160

Nuh, M. (2017). Pengaruh Suhu dan Lama Ekstraksi terhadap Mutu Pektin Kulit Pisang kepok. 6(2), 144-148.

Romelle, F. D., Rani, P. A., \& Manohar, R. S. (2020). Chemical composition of Some Selected Fruit Peels. European Journal of Food Science and Technology, 4(4), 12-21.

Rudra, S. G., Hanan, E., Sagar, V. R., Bhardwaj, R., Basu, S., \& Sharma, V. (2020). Manufacturing of mayonnaise with pea pod powder as a functional ingredient. Journal of Food Measurement and Characterization, 14(5), 2402-2413. https://doi.org/10. 1007/s11694-020-00487-0

Safitri, A. R., Evanuarini, H., \& Thohari, I. (2019). The effect of ginger extract on emulsion stability, total acidity and sensory evaluation of full fat mayonnaise. International Research Journal of Advanced Engineering and Science, 4(4), 284-289. https://doi.org /10.5281/ZENODO.3580426

Shin, J.-E., Cornillon, P., \& Salim, L. (2002). The effect of centrifugation on agar/sucrose gels. Food Hydrocolloids, 16(2), 89-94. https://doi.org/10.1016/ S0268-005X(01)00058-3

Subagyo, P. (2014). Pemungutan pektin dari kulit dan amapas apel secara ekstraksi. Eksergi, 10(2), 47-51. https://doi.org/ 10.31315/e.v10i2.340 